\title{
Study of indoor performances of a building using Rammed earth
}

\author{
Wiçal CHEIKHI ${ }^{1}$; Khadija BABA ${ }^{1}$; Sidi Mohamed LAMRANI ${ }^{2}$; Abderrahmane NOUNAH ${ }^{1}$; Mohamed KHALFAOUI $^{2}$; \\ Lahcen $\mathrm{BAHI}^{3}$ \\ ${ }^{1}$ GCE Laboratory, High School of Technology -Sale-, Mohammed V University in Rabat, Morocco \\ ${ }^{2}$ ASTIMI Laboratory, High School of Technology -Sale-, Mohammed V University in Rabat, Morocco \\ ${ }^{3}$ 3GIE Laboratory, Mohammedia School of Engineering, Mohammed V University in Rabat, Morocco
}

\begin{abstract}
Nowadays, many assumptions hold that returning to rammed earth construction could be a solution to the energy challenges of the time. These assumptions are based on the ability of the material to maintain a comfortable indoor temperature regardless of the outdoor climatic variations. However, its influence on the energy performance of buildings remains little explored so far. This paper comes in this order of ideas. It is devoted to study and evaluate the energy efficiency of rammed earth buildings compared to those in concrete structure and masonry envelope. It takes as case study two buildings: one is traditional, entirely built with the technique of rammed earth; the other is constructed of concrete. In order to compare between their performances, we have performed a simulation of the thermal behavior of each by the dynamic thermal simulation software Design Builder.
\end{abstract}

\section{Introduction}

Since the beginning of its use in the construction industry, the rammed earth always proved it reliability as much as local, ecological material implementing excellent thermal properties. Indeed, whatever the climatic context of their establishment, rammed earth constructions are able to get freshness in summer and tepidity in winter. This property makes it possible to reduce the recourse to the systems of air-conditioning and heating, leading to an abusive consumption of energy.

In a world context centered on sustainable development and energy efficiency, working to reduce the energy consumption of the buildings becomes a major requirement. Indeed, on the national scale, construction industry, formed in majority of modern buildings, is today responsible for $36 \%$ of the total energy intake and $51 \%$ of the electricity's consumption [1]. Alarming figures, which invite all the speakers in the sector of the building to suggest effective and accessible solutions in order to improve the thermal performances of the envelope, regarded as the primary source of the energy losses. In this direction, several research tasks were undertaken, suggesting capable solutions to improve energy quality of the envelope. Soebarto \& al. [2] carried out a study about the indoor performance of rammed earth houses. The study compared between the performances of two existing houses in Willunga, South Australia: the one uses rammed earth as the sole wall material and the second uses insulated rammed earth walls. The results showed that the insulated house could be 5 degrees warmer than the uninsulated one, and would potentially use less energy for heating.

The renovation of social accommodation which gives an occasion interesting for the reduction of the power consumption and the increase of the comfort of the inhabitants was studied by Gagliano \&al. [3]. The improvement of the thermal insulation of the building envelope and the use of renewable energy's sources was offered, what drove to an economy of energy and to an increase of comfort. From his part,

Jaher \&al. [4] led a dynamic thermal simulation aiming at the valuation of the thermal quality of the rammed earth used as an external cladding of a low-cost house in Bangladesh. The results of simulation showed that net improvements concerning thermal comfort and power consumption could result from the usage of the rammed earth applied as external cladding. Following the same logic, the present paper consists of establishing a comparative study between the thermal performances of rammed earth buildings and those in concrete; with an objective to show the interest of the use of the rammed earth that could be considered as energy-performance improvement in the contemporary building. Comparison is led on a building in rammed earth and a second variable of the same building constructed in concrete. The studied building is a residential type, constructed in two levels. The objective of this job is to show the influence of the material's envelope used to improve the thermal comfort of the building and as a result, the 
lightering of heating and air-conditioning costs. Simulation registers as part of Moroccan thermal regulation and is insured by both software BLOCK LOAD [5] and DESIGN BUILDER [6].

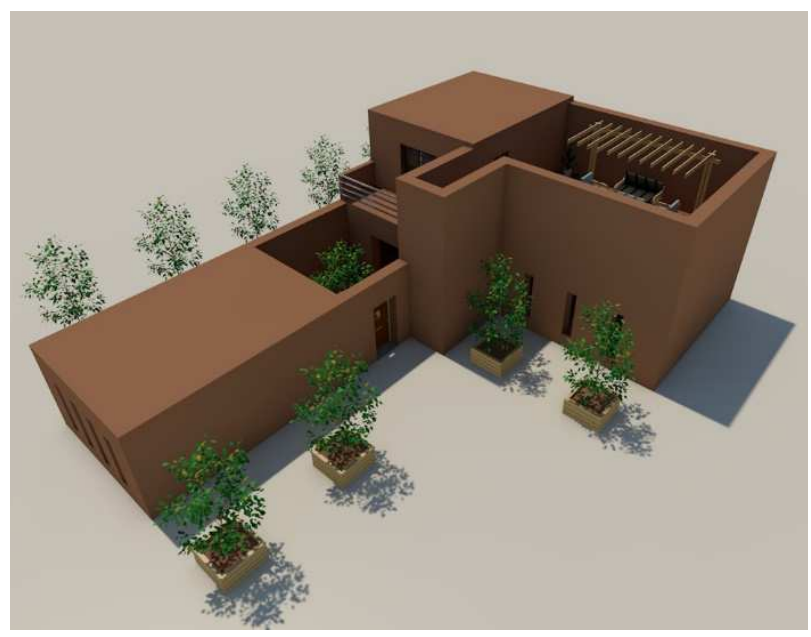

Fig. 1. 3D view of the studied building

\section{Case study description}

The studied building is a project under construction located in the peripheral zone of Marrakech city (Morocco, climatic zone 5), at about fifteen kilometers of the city center of this one. The building is a residential type family house (five persons) and composed of a ground floor and a first floor (see figure1). The ground floor spreads out on an area of 143Sqm and articulates around a patio which distributes the kitchen on the one side, the living area on the other one. The first floor has a surface of $90 \mathrm{Sqm}$, composed mainly of the master bedroom, which opens on a patio and is provided with a balcony (Figure2).

Fig. 2. Orientation and building layout
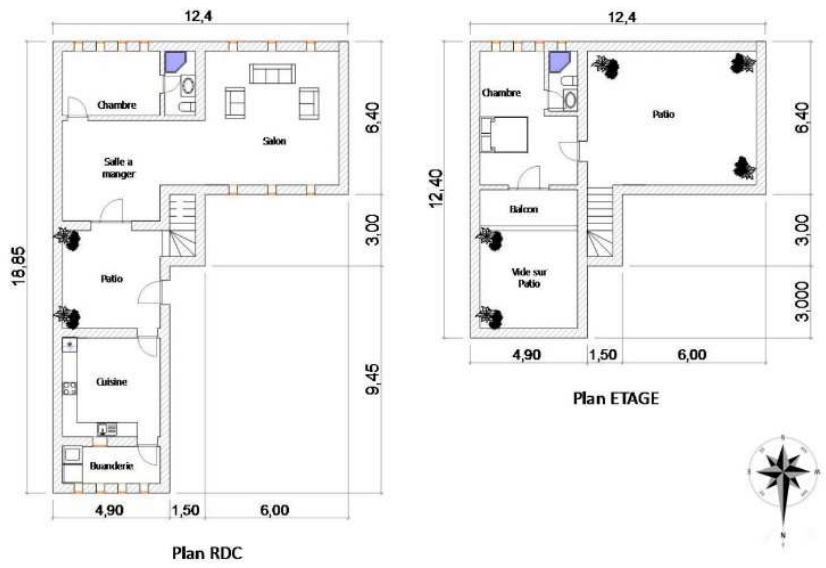

The building has an interesting orientation: the living rooms (bedrooms and living room) are facing the south, while the laundry room is located in the opposite direction (north) (Figure 2). This arrangement gives the possibility to enjoy the passive solar contributions in the living room and to create a buffer zone (laundry) protecting the building from thermal losses to the north. The organization of the building around the patio gives the possibility to improve the natural lighting and thus reduce the use of artificial lighting devices. From an air circulation point of view, the building benefit from two natural ventilation modes: horizontal ventilation through the different windows; another vertical being made through the opening of the building on the Patio. The latter allows the air circulation by chimney effect. Effective ventilation device in arid regions, known for its ability to minimize overheating in summer.

\section{Walls composition study}

\subsection{Initial Option (Rammed earth)}

The original building is entirely built with the traditional technique of Rammed earth. All the vertical walls (façade walls and partitions) are composed of a mixture of $2 / 3$ clay for $1 / 3$ straw. The roof is made up of wooden beams, joists and a reed grid. The outer walls have a thickness of $0,4 \mathrm{~m}$, which is considered to be the minimum thickness for earth constructions. The thermophysical characteristics of the building walls have previously been the subject of an experimental study. It was based on the steady state asymmetric hot plate method [7] to determine the thermal conductivity $(\lambda)$, the asymmetrical transient Hot Plate method to measure the effusivity (e), and the flash method [8] to determine the diffusivity (a) of the mixture used in the construction of our building. The experimental values found and used in our study are summarized in the table1.

Table 1. Thermophysical characteristics of the used Rammed earth

\begin{tabular}{lc}
\hline $\begin{array}{l}\text { Thermal conductivity } \\
\lambda \quad(W . m-1 . K-1)\end{array}$ & $\mathbf{0 , 4 6 3}$ \\
\hline $\begin{array}{l}\text { Thermal diffusivity } \\
\text { a.10-7 (m2.s-1) }\end{array}$ & 3,13 \\
\hline $\begin{array}{l}\text { Thermal effusivity } \\
\text { a (w. s1/2.m-2.K-1) }\end{array}$ & 648,07 \\
\hline $\begin{array}{l}\text { Specific heat } \\
\text { C (J.Kg-1.K-1) }\end{array}$ & 1128,59 \\
\hline Density $\boldsymbol{\rho}(\mathbf{k g} / \mathbf{m} 3)$ & 1310,69 \\
\hline
\end{tabular}

\subsection{Comparison Option (Masonry)}

In order to compare the thermal performance of rammed earth building with masonry buildings, we have created a second variant of the studied building: it is a reinforced concrete structure and a masonry envelope. It corresponds to the model of construction in masonry usually used in the Moroccan context. The composition of this variant's walls is summarized in the table below. 
Table 2. Envelope composition of the Masonry option

\begin{tabular}{|c|c|c|c|}
\hline Envelope & External walls & $\begin{array}{c}\text { Roof slab } \\
\text { and } \\
\text { Intermediate } \\
\text { slab }\end{array}$ & $\begin{array}{c}\text { Ground } \\
\text { slab }\end{array}$ \\
\hline $\begin{array}{l}\text { Width } \\
\text { (m) }\end{array}$ & 0,30 & 0,25 & 0,40 \\
\hline $\begin{array}{l}\text { Structure } \\
\text { (From } \\
\text { external } \\
\text { to } \\
\text { internal) }\end{array}$ & $\begin{array}{c}\text { Lime } \\
\text { Plaster/cement } \\
\text { Hollow block } \\
6 \text { holes } \\
\text { Air chamber } \\
\text { Hollow block } \\
12 \text { holes } \\
\text { Lime } \\
\text { Plaster/cement }\end{array}$ & $\begin{array}{l}\text { Interior } \\
\text { plaster } \\
\text { Slab } \\
\text { Waterproof } \\
\text { bitumen } \\
\text { Screed to } \\
\text { fall } \\
\text { Finishing } \\
\text { screed } \\
\text { Floor tiles }\end{array}$ & $\begin{array}{l}\text { floor tiles } \\
\text { Finishing } \\
\text { screed } \\
\text { Screed to } \\
\text { fall } \\
\text { Concrete } \\
\text { slab } \\
\text { Polyane } \\
\text { Layer } \\
\text { Sand } \\
\text { Gravel } \\
\text { layer }\end{array}$ \\
\hline $\begin{array}{l}\text { U Value } \\
\left(\mathbf{W} / \mathbf{m}^{2} . \mathbf{K}\right)\end{array}$ & 1,96 & 2,04 & 1,60 \\
\hline
\end{tabular}

To calculate the $U$ value, we took account of the external and internal surface resistances, Rse and Rsi

\section{Energy simulation of the Buildings}

\subsection{Building Thermal summary}

The thermal summary of the building is made using the software package Block Load. This calculates summer/winter loads for buildings. Heating and cooling requirements can be calculated also. This package uses the response factor method to calculate the loads. This method is approved by ASHRAE as a suitable method for the calculation of hourly loads. For our study, the objective behind the installation of the thermal balance is to quantify the energy consumption of the two variants to be compared (rammed earth variant and masonry variant). The results are shown in the attached tables.

Table 3. Characteristics of air conditioning equipment for both variants

\begin{tabular}{ccc}
\hline Option & Masonry & Rammed earth \\
\hline $\begin{array}{c}\text { Heating capacity } \\
\text { (kw) }\end{array}$ & 32,2 & 29,3 \\
\hline $\begin{array}{c}\text { Cooling Capacity } \\
\text { (kw) }\end{array}$ & 13,2 & 10,6 \\
\hline $\begin{array}{c}\text { Equipement } \\
\text { Characteristics }\end{array}$ & $\mathrm{EER}=3,05$ & $\mathrm{EER}=3,05$ \\
& $\mathrm{COP}=4,09$ & $\mathrm{COP}=4,06$ \\
\hline
\end{tabular}

It is important to note that the coefficient of performance (COP) of the equipment required to heat the masonry variant of the building is slightly higher than the rammed earth version. While the cooling equipment EER is equal for both variables. In the light of this observation, it is possible to argue that rammed earth buildings allow a better conservation of heat compared to those in masonry.

\subsection{Dynamic thermal simulation}

Dynamic thermal simulation (DTS) simulates the behavior of the building hour by hour. To do this, the simulation is carried out using the Design Builder software which uses the dynamic simulation engine EnergyPlus to model the thermal performances of the building. This takes into account the following parameters:

- Location of the building, local weather

- The orientation of the building, the distribution of parts and glazing

- The materials structure of the building, its thermal inertia, its thermal bridges, its solar protection, etc.

- Heating, air conditioning, DHW production, ventilation, lighting

- The occupation of the parts and the behavior of the users

- Regulation of heating and possibly other equipment.

For each of the two studied variables, our building was subdivided into several thermal zones according to the scope of each, their location and whether they are covered or not (in the case of the patio and the balcony). Six (6) areas resulted from the ground floor and Four (4) from the first. The wall compositions used for each variable are summarized in Table 1 for the rammed earth construction variant and in Table 2 for the masonry variant. The heating setpoint temperature was set at $20^{\circ}$ $\mathrm{C}$ and the cooling temperature was set at $26^{\circ} \mathrm{C}$. We then defined the number of users of the building (five people) and an annual schedule for the occupancy and use of heating and air-conditioning equipment.

We then proceeded to define the outputs of the simulation. These include the internal temperature of each studied space, radiant temperatures, thermal losses, heating and cooling requirements and the total energy consumption of the building.

\section{Results of the simulation}

To compare the energy requirements in ( $\mathrm{kWh} / \mathrm{m} 2 /$ year) of the heating and cooling of rammed earth buildings and concrete ones, we proceeded to simulate the energy requirements for the following two cases:

- Walls of $30 \mathrm{~cm}$ in double wall of masonry.

- Walls of $40 \mathrm{~cm}$ built in rammed earth. 
The results of the dynamic energy simulation carried out on the Design Builder software show the following:

- Improved operating and radiant temperatures minimizing the "cold wall" sensation due to the temperature difference between the air and the wall surface (table 4).

Table 4. Temperatures in both options

Option Masonry Rammed earth

Air temperature $\left({ }^{\circ} \mathrm{C}\right)$

19,96

\begin{tabular}{ccc} 
Radiant temperature & 15,12 & 16,65 \\
$\left({ }^{\circ} \mathbf{C}\right)$ & \\
\hline
\end{tabular}

Operative

temperature $\left({ }^{\circ} \mathrm{C}\right)$

- A significant reduction in thermal losses through walls, the top and bottom floors are recorded in the rammed earth construction variable compared with the masonry (Figures 3 and 4 and table 5).

Fig. 3. Heat losses in the rammed earth option

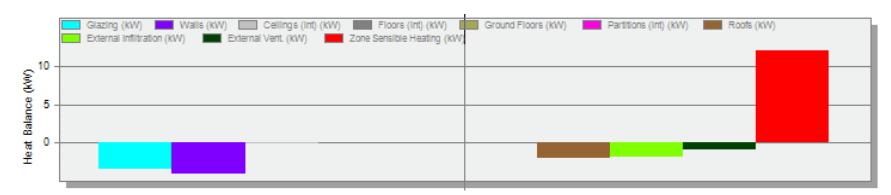

Fig. 4. Heat losses in the masonry option

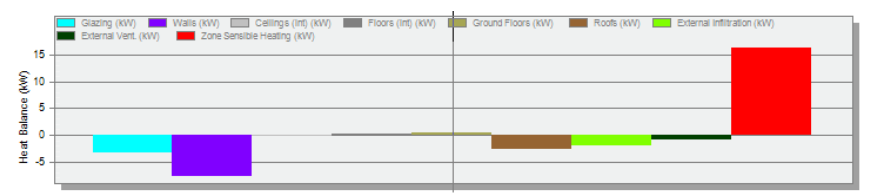

Table 5. Heat losses in both options

\begin{tabular}{|c|c|c|}
\hline Heat loss (KW) & Masonry & Rammed earth \\
\hline Walls & 7,75 & 4,11 \\
\hline Roofs & 2,73 & 1,94 \\
\hline
\end{tabular}

- A decrease in heating requirements is noted for the building constructed in rammed earth. Table 6 shows a reduction in heating requirements which is as high as $32 \%$ compared to the masonry variant.

- A $26 \%$ increase in air conditioning needs is noted in the rammed building (Table 6) compared to the masonry variant. The air conditioning loads are increased because their walls with high thermal inertia characterize the rammed constructions. This inertia lead the heat coming from the diurnal solar radiation to be absorbed, stored and then trapped inside the walls. Its evacuation will require more time and will induce the use of air conditioning to compensate the sensation of thermal discomfort caused by this trend.

Table 6. Annual Heating and Cooling demand

\begin{tabular}{lcc}
\hline Option & $\begin{array}{c}\text { Heating } \\
\text { demand } \\
{[\mathbf{k W h} / \mathbf{m} 2]}\end{array}$ & $\begin{array}{c}\text { Cooling } \\
\text { demand } \\
{[\mathbf{k W h} / \mathbf{m} 2]}\end{array}$ \\
\hline Rammed earth & 33.96 & 668.68 \\
\hline
\end{tabular}

$\begin{array}{ll}\text { Masonry } & 49.94\end{array}$

\section{Conclusion}

Dynamic thermal simulation of the two variants (rammed earth and masonry) of the studied building allowed us to obtain temperature graphs, a quantification of the heating and cooling needs, a thermal loss reading ... All these results, to compare the thermal performance of rammed earth and masonry constructions and to identify the strengths and weaknesses of each. The conclusions drawn from the study are as follows:

- Rammed earth is an ecological, renewable and energy-saving building material. It fits perfectly into the energy efficiency approach.

- The use of rammed earth in construction makes it possible to reduce certain trends observed in masonry construction. We enumerate as an example the phenomenon of cold walls.

- The rammed earth is a material with high thermal inertia. Nevertheless, this feature should be considered with caution: If it reduces heating requirements considerably in the winter, it causes an increase in the air conditioning load in summer. Indeed, the walls with high thermal inertia absorb the heat of the solar radiation, store it and restore it in phase shift (in offset with the absorption time). This makes it possible in winter to 
extend the feeling of thermal comfort and reduce the use of heating systems, resulting in a gain of more than $30 \%$ in the energy load. While in the summer, the restitution of the phase-shifted heat flux on the contrary extend the sensation of overheating, inducing an additional use of the cooling systems. In order to reduce the consequences of this phenomenon it is recommended to:

- Decrease the overall rate of bay windows in rammed earth constructions. The more windows there are, the more the building will absorb heat. It is remarkable that the traditional rammed earth constructions of the South of Morocco are opaque buildings, benefiting only from very limited surfaces of openings. However, they are nonetheless sheltered from external climatic variations, providing freshness in summer and tepidity in winter.

- $\quad$ Promote the use of fixed shading devices (awning) for south-facing openings. This allows the building to benefit from passive solar contributions in winter and to reduce overheating in summer.

- Promote overnight ventilation by creating air chimneys, transverse ventilation, ventilation grilles, etc. This action allows the surplus heat accumulated during the day to be evacuated more quickly, thus reducing the need for air conditioning during the summer days.

\section{References}

1. Agence internationale de l'énergie, Morocco (2009).

2. Soebarto Veronica., Analysis of Indoor Performance of Houses Using Rammed Earth Walls, Eleventh International IBPSA Conference Glasgow, Scotland, 1530-1537, (2009).

3. A.Gagliano, F.Nocera, F.Patania, G.Capizzi, A case study of EnergyEfficiency Retrofit in social housing units; EnergyProcedia 42, 289 - 298, (2013).

4. Jaher Wasim, The effects of rammed earth on thermal comfort and energy consumption of a bungalow in Bangladesh, Procedia environmental sciences (2017).

5. Software package Block Load, for calculating the thermal summary of the building.

6. Design Builder Software Ltd, 2009. DesignBuilder 2.1 User's Manual. Available at: http://www.designbuilder.co.uk/component/option,com_d ocman/task,cat_view/gid,20/Itemid,30/.

7. Y Jannot, V Felix, A Degiovanni, A centered hot plate method for measurement of thermal properties of thin insulating materials, Measurement Science and Technology, Volume 21, Number 3 (2010).

8. Parker, W. J.; Jenkins, W. J.; Butler, C. P. and Abbott, G. L., Flash method of determining thermal diffusivity, heat capacity and thermal conductivity. J. App. Physics, 32: (9), 1679-1684. (1961).

9. T.T. Bui, A. Mesbah, S. Maximillien, A. Limam, Behavior of rammed earth walls under compression or shear stress, J. Mater. Environ. Sci. 7 (10), 3584-3594, (2016)

10. Lucile Soudani, Antonin Fabbri, Monika Woloszyn, Pierre-Antoine Chabriac, Anne-Cécile Grillet, JeanClaude Morel, Étude de la pertinence des hypothèses dans la modélisation hygrothermique du pise, proceeding of Conférence IBPSA France-Arras, (2014)

11. David Allinson, Matthew Hall, Hygrothermal analysis of a stabilised rammed earth test building in the UK, Energy and Buildings 42, 845-852, (2010).

12. G. Minke, Earth Construction Handbook: The Building Material Earth in Modern Architecture, Southampton, WIT Press (2000).

13. J.D. Revuelta-Acosta, A. Garcia-Diaz, G.M. SotoZarazua, E. Rico-Garcia, Adobe as a sustainable material: a thermal performance, Journal of applied sciences 10 (19), 2211-2216, (2010).

14. Julien Borderon, Richard Cantin, Joseph Virgone, Etude du comportement thermique dynamique de l'enveloppe non isolée du bâtiment : cas des murs inertes, proceeding of Conférence IBPSA France -Lyon (2008). 15. Lucile Soudani, Antonin Fabbri, Monika Woloszyn, Pierre-Antoine Chabriac, Anne-Cécile Grillet, JeanClaude Morel, Étude de la pertinence des hypothèses dans la modélisation hygrothermique du pise, proceeding of Conférence IBPSA France-Arras (2014).

16. Morel J C, Mesbah A, Oggero M and Walker P. Building houses with local materials: means to drastically reduce the environmental impact of construction, Building and Environment 36, 1119-1126, (2001). 17. Paul W L, Taylor P A. A comparison of occupant comfort and satisfaction between a green building and a conventional building, Building and Environment 43, 1858-1870, (2008).

18. Ranime El Nabouch, Q.-B. Bui, P. Perrotin, O. Ple, J.-P. Plassiard, Modélisation numérique de structures en pisé : analyses et recommandations, Rencontres Universitaires de Génie Civil, Bayonne, France. Hal 01167665 (2015).

19. Taylor P, Fuller R J, Luther M B. Energy use and thermal comfort in a rammed earth office building, Energy and Building 40, 793-800, (2008). 